\title{
Wildlife rescues - the case of the Petit Saut hydroelectric dam in French Guiana
}

\author{
Jean-Christophe Vié
}

\begin{abstract}
Many wildlife rescues have been carried out over the past few decades but most were not documented and were controversial. However, such operations can be useful, providing risks are evaluated and elementary guidelines are followed. In addition to saving lives and being desirable from an ethical point of view, such operations can be very valuable for both biological research and conservation, and are certainly preferable than the alternative: to do nothing. Previous rescues are reviewed and the operation conducted in French Guiana during the filling of the Petit Saut reservoir is described. Object-
\end{abstract}

ives, methods, results and financial aspects are discussed. Around 5500 mammals and reptiles were captured, sampled and translocated to a protected area. The successful results of the translocation, the large amount of original data obtained, the interest shown by scientists in our samples and the subsequent new conservation impetus that appeared in the government corroborate our initial conviction that the operation was worthwhile.

Keywords Dam, French Guiana, tissue bank, translocation, wildlife rescue.

\section{Introduction}

Habitat loss on a large scale is the inevitable consequence of hydroelectric dams in lowland Neotropical forests (Sioli, 1986; Gribel, 1993). Large areas are flooded, killing trees and threatening wild animals with drowning or starvation. Many species are able to swim or escape using the forest canopy, but the size of the reservoir, habitat fragmentation, territoriality of the species affected and the fact that some animals move slowly, make human intervention necessary to give other species a chance of survival. Wildlife rescues and translocations have been organized during the filling of reservoirs since 1964 in Suriname, Venezuela, Costa Rica, and above all in Brazil in the 1980s. In some cases, these operations were unplanned, undocumented and not evaluated. Generally, rescued animals were not monitored after their release, making objective assessment impossible.

Rescue operations are labour-intensive and expensive (Nielsen, 1988) and involve certain risks (Woodford \& Rossiter, 1993). Detractors also consider them worthless

Jean-Christophe Vié Programme Faune Sauvage, EDF/CNEH Savoie Technolac, 73373 Le Bourget-du-Lac Cédex, France. Present address: Association Kwata, BP 672, 97335 Cayenne Cédex, French Guiana. Tel/Fax: + 5942543 31; e-mail: kwata@nplus.gf

Received 11 February 1998. Accepted 8 September 1998 in relation to the large-scale damage caused to natural ecosystems. However, on one hand, the need for better documentation of wildlife rescues has been emphasized (Malik \& Johnson, 1994; Hodder \& Bullock, 1997) and, on the other hand, there is a consensus that the risks may be worth taking to minimize unacceptable wastage of wild species, as long as guidelines are respected and a suitable release area is chosen (Konstant \& Mittermeier, 1982; Gribel, 1993).

This paper first reviews previous rescue and translocation operations, and then describes a case study in French Guiana.

\section{Overview of past wildlife rescues and translocations}

Translocation is defined as a 'deliberate and mediated movement of wild individuals or populations from one part of their range to another' (IUCN, 1995). In the past it was used mostly for ungulates and carnivores (Harthoorn, 1962). More recently its use has been extended to a wide variety of taxa including invertebrates and plants (Hodder \& Bullock, 1997). Between 1973 and 1986, an annual average of 700 translocations were conducted in Australia, Canada, New Zealand and the USA, most of them for hunting purposes (Griffith $e t$ al., 1989). Ninety-eight per cent of these were conducted in North America. In the USA alone, in 1985, translocations were carried out in 64 per cent of the states (Boyer \& Brown, 1988). In France translocations have been 
used for ungulates since the 1950s (Berducou, 1990). The success of these operations increased with technological improvements (Nielsen, 1988), and multidisciplinary approaches, and probably benefited from experience of past failures or disasters. However, the dangers of these operations have been widely outlined (Konstant \& Mittermeier, 1982; Griffith et al., 1989; Cunningham, 1996; Hodder \& Bullock, 1997), especially in terms of disease risks (Woodford \& Rossiter, 1993; Karesh \& Cook, 1995).

Today, translocations are conducted mainly to conserve wildlife populations and as a rescue method in an emergency (Table 1). Other reasons exist: sentimentality, curiosity or compassion (Andau et al., 1994); hunting or fur production (Nielsen, 1988; Berducou, 1990); ethical and aesthetic considerations (Ehrlich \& Wilson, 1991; Hodder \& Bullock, 1997); cultural and religious considerations (Malik \& Johnson, 1994); reduction of human-wildlife conflict (Konstant \& Mittermeier, 1982; Strum \& Southwick, 1986; Malik \& Johnson, 1994).

Wildlife rescues and translocations have been carried out world-wide but very few have been documented or discussed. Some are performed without publicity. In the Netherlands, an estimated 40,000 birds are rescued each year (Dorrestein et al., 1994), 25 times the number rescued after the Exxon Valdez oil spill in Alaska (Holcomb, 1991; Monahan \& Maki, 1991), and about 45 times the number rescued after the Amoco Cadiz oil spill in France (Monnat \& Guermeur, 1979). Rescue efforts may focus on a single charismatic and endangered mammal species, such as sea otters (Loughlin, 1994), howler monkeys (Rodríguez-Luna et al., 1993) or orangutans (Andau et al., 1994). In the latter two cases, the rescue efforts were necessary when habitat fragmentation threatened population viability.

In the last 40 years, many large dams have been built in lowland tropical areas in Africa, Asia and South America, creating large artificial lakes (Sioli, 1986) but information about rescues and translocations is scarce. In some cases, such as for the rescue carried out at the 4240-sq-km Guri reservoir in Venezuela (Kinzey et al., 1988), it was impossible to obtain first-hand information (Konstant \& Mittermeier, 1982). Nakhasathien (1989) described the frustrations of the Chiew Larn dam rescue in Thailand. The first known rescue was organized during the filling of the 5460-sq- $\mathrm{km}$ Kariba lake in Zimbabwe between 1958 and 1961 (Smithers, 1959; Child, 1968). It resulted in the capture of 3175 mammals; an additional 299 large mammals were driven to safety. Mortality was monitored and evaluated at 7.5 per cent during the rescue operation but very few observations of released animals were reported (Child, 1968). The first dam to be completed in a Neotropical forest was Brokopondo in Suriname (Sioli, 1986). The rescue was improvised and only a list of 'saved' animals was reported (Walsh \& Gannon, 1967). The largest operation of this kind took place in Brazil at Tucuruí (Eletronorte, 1985; Mascarenhas \& Puorto, 1988; Gribel, 1993). More than 280,000 animals were captured but in the absence of planning the animals were released outside protected areas, on the overcrowded reservoir bank (Peres \& Jones, 1991-92; Gribel, 1993) and sometimes in areas that were destined to be flooded (Mascarenhas \& Puorto, 1988). Only a few animals were tagged for future monitoring and no post-release survey was conducted (Mascarenhas \& Puorto, 1988). In subsequent Brazilian operations at Balbina and Samuel, except for most common species, the majority of the rescued animals were sent to scientific institutions for experimental research or zoological collections (Eletronorte, 1988, 1989; Ghilardi \& Juras, 1991).

\section{The Petit Saut rescue operation}

Between January 1994 and July 1995, 365 sq km of primary rain forest were flooded after the closing of the Petit Saut dam on the Sinnamary River in French Guiana $\left(5^{\circ} 4^{\prime} \mathrm{N}, 53^{\circ} 03^{\prime} \mathrm{W}\right)$. The flooding created hundreds of islands of various sizes covering a total area of $105 \mathrm{sq} \mathrm{km}$. A scientifically oriented rescue operation was planned and undertaken.

\section{Objectives}

Human aspects

In the case of a large construction, such as the Petit Saut dam, companies have legal obligations and, in this framework, a wildlife rescue was recommended (Sissakian \& Vié, 1997). The first objective was to 'save' doomed animals. Both political and emotional factors led to the decision to organize a rescue but it soon became apparent that it would be necessary, for scientific purposes, to optimize animal captures and releases, and to undertake follow-up studies to evaluate the outcome of the rescue.

Moreover, as previously outlined, good science, love or emotion are not incompatible (Orr, 1992) nor are conservation and science (Erwin, 1991). However, the lack of cohesion between field conservationists and scientists persists (Sarrazin \& Barbault, 1996), despite the development of conservation biology (Soulé, 1986).

\section{Scientific considerations}

A rescue was worthwhile only if the operation were based on a multidisciplinary scientific approach. Many aspects of Neotropical rain-forest wildlife remain unknown (Emmons \& Feer, 1997). The rescue provided a unique opportunity to inventory, sample and study 


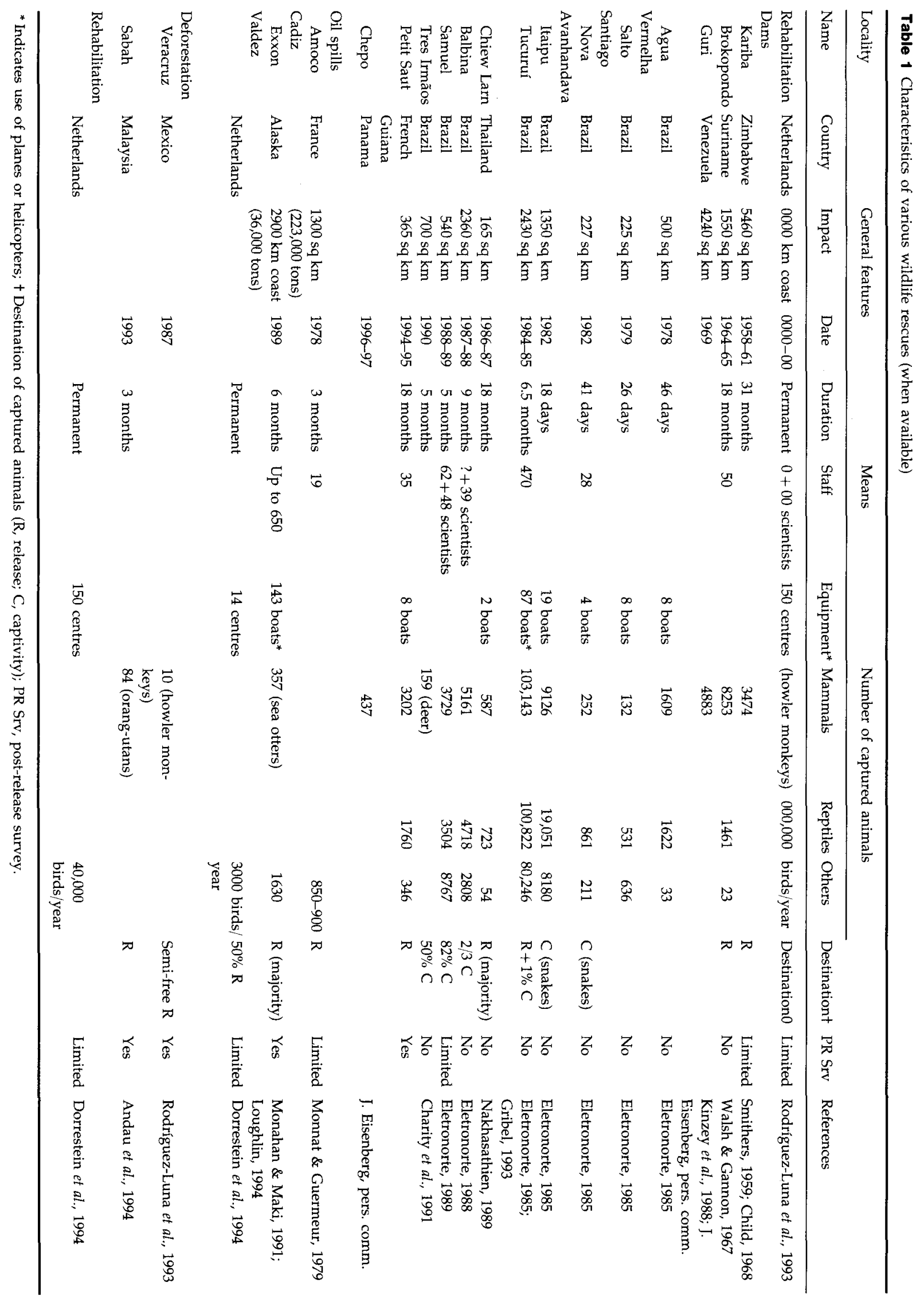

(C) $1999 \mathrm{FFI}$, Oryx, 33(2), 115-126 
species that are very difficult to observe or capture under normal conditions, and also offered an opportunity to gain easy access to the forest canopy.

The interest of such a unique opportunity had been already outlined in 1959 at the Kariba lake in Zimbabwe (Smithers, 1959). More recently, Sarrazin \& Barbault (1996) expressed the same feeling, emphasizing the interest of reintroductions as a way to experiment in ecology and to study the role of keystone species in community ecology. For ethical reasons, it is generally impossible to experiment. Planned rescues and reintroduction projects give an opportunity to study community ecology by looking at large perturbations.

\section{Importance of biological banks}

Biological banks have become a priority today (Dessauer \& Hafner, 1984; Catzeflis, 1991; Woodford \& Rossiter, 1993). Preserved tissues can be very useful in the detection of emerging diseases, clarifying the epidemiology of various tropical diseases, investigating declining animal populations and characterizing the genetic variability of different species.

\section{Conservation considerations}

Translocation can be an efficient conservation tool, but has been rarely used in the Neotropics. We had an opportunity to translocate large numbers of species, optimize translocation methods, document their efficiency and gain experience with doomed but otherwise healthy populations before they became truly threatened (Strum \& Southwick, 1986). For example, if documented, the results of the previous translocations of red howler monkeys in Suriname, Venezuela and Brazil (Walsh \& Gannon, 1967; Eletronorte, 1988; J. Eisenberg, pers. comm.) could have been used in translocation projects involving endangered Central American howler species (Horwich et al., 1993; Rodríguez-Luna et al., 1993).

France is the only developed country that owns a large and almost intact tropical rain forest. Paradoxically, until the filling of the Petit Saut dam, French Guiana was the only South American country without a large rain-forest protected area. It also has no hunting legislation, probably for cultural and political reasons, but also partly because of a lack of data on the biology of game species and hunting effects on wildlife (de Thoisy \& Vié, in press).

In addition, rescues appeal to people, and attract public and media attention, thereby raising public awareness of local environmental problems. They also have the particularity of not being restricted to a single charismatic species (Dietz et al., 1994). Given the difficulty of filming or photographing Guianan animals, the operation provided an opportunity to acquire the type of visual support necessary for public education.
Financial aspects

Funding is a major problem for conservation programmes (Soulé, 1991) and balancing ethical and economic considerations remains difficult (Morowitz, 1991). This is particularly true in France, which has a poor conservation tradition. Moreover, corporate or public money dedicated to a rescue would never be available for other conservation projects or habitat protection. The wildlife rescue allowed the creation and funding of a large research programme and initiated the first field veterinary and genetic study in the country.

\section{Summary of objectives}

Thus, the following objectives were defined: (i) capture and translocate as many threatened animals as possible; (ii) hold the animals in captivity for the shortest possible time; (iii) return healthy animals to the wild; (iv) document the post-release survival of several target species; (v) build a tissue bank and database on Guianan wildlife; (vi) centralize and share information and material with the international scientific community; and (vii) provide education on Guianan wildlife conservation to visitors.

\section{Methods}

We attempted to follow IUCN guidelines for reintroductions (IUCN, 1995), published recently (IUCN, 1998), and other recommendations for translocations (Konstant \& Mittermeier, 1982; Caldecott \& Kavanagh, 1988; Nielsen, 1988; Woodford \& Rossiter, 1993).

\section{Choice of a suitable release area}

A release area with a similar habitat was chosen close to the dam (Fig. 1) to avoid the inadvertent introduction of disease and genetic pollution, and also to minimize stress during transportation. We were not able to determine pre-flooding genetic differentiation across this region for translocated species but, based on one published study of genetic variation in mammalian populations in Neotropical forests (da Silva \& Patton, 1993), we judged that the risk was minimal. The release area was already partially disturbed by logging and heavily hunted; this may actually have enhanced translocation success by reducing the densities of some resident populations (Andau et al., 1994; Kleiman et al., 1994). Limited access to the area made control possible and for the first time in French Guiana a large rain forest area, including the reservoir and release areas, was effectively protected against hunting by decree and guards. In the French Guianan political and cultural context this should be considered as a great first step for wildlife conservation.

\section{Captures}

Our effort was constrained by economic criteria and 


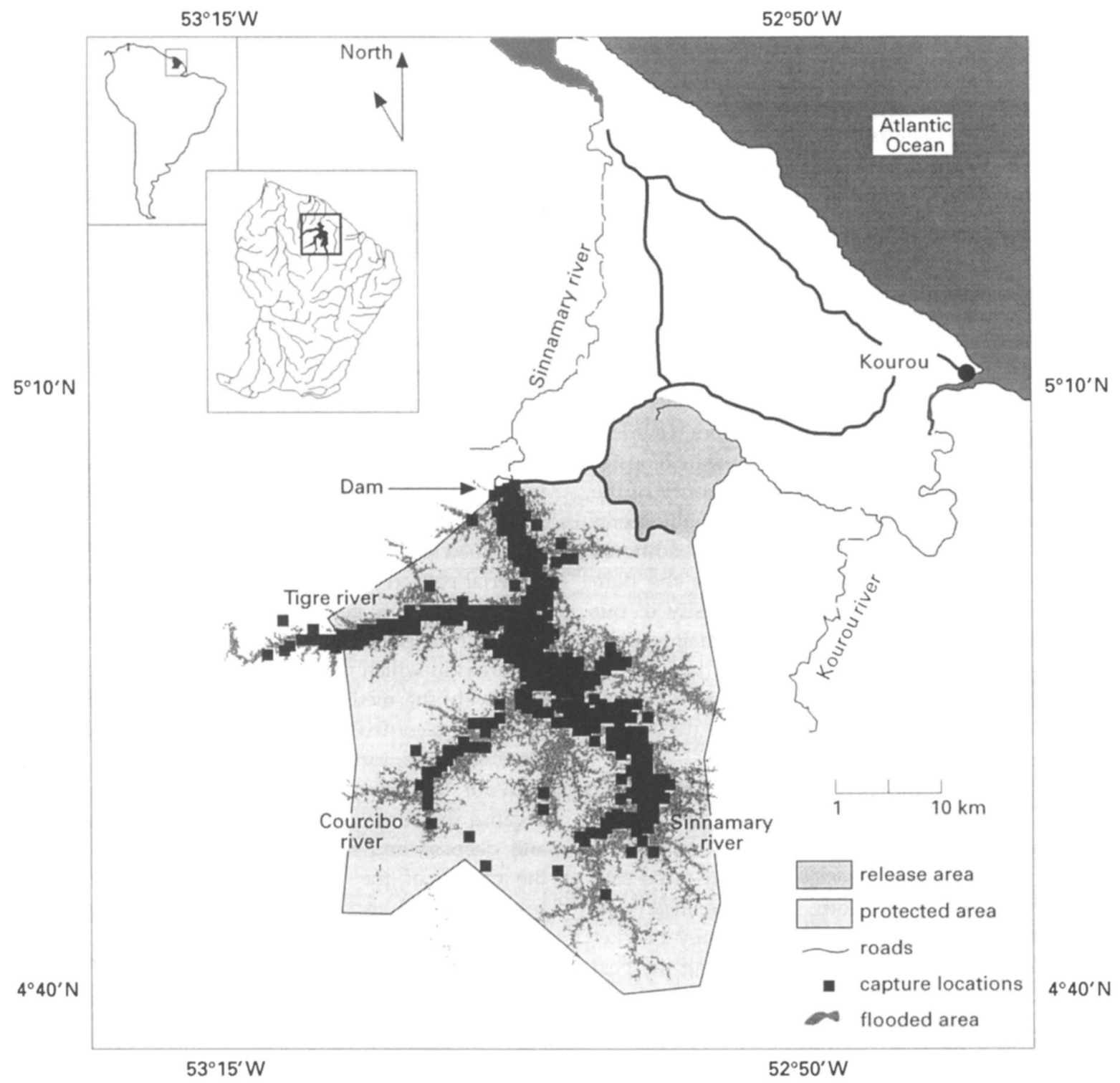

Fig. 1 Study area and distribution of capture locations (black squares: $463 \mathrm{~m}$ (0.25 nautical mile) per side).

utility. We decided to focus on medium and large mammals $(>200 \mathrm{~g}$ ), tortoises and snakes. Forty-ninenon-volant mammal species weighing over $200 \mathrm{~g}$ were present in the rescue area (Emmons \& Feer, 1997; pers. obs.) and one tortoise species. Ninety-five snake species have been recorded from French Guiana (Vidal et al., in press) including $c .75$ forest species probably present in the study area. Up to 35 people (veterinarians, biologists, students and local workers) worked on the operation. Capture effort was estimated by the cumulative number of boats employed per day.

Among the mammals, most species could swim and probably did but smaller species were often stranded. Mammal densities on the islands in the reservoir and around its edges increased. Many arboreal species were able to escape in the continuous forest canopy but many individuals stayed in their shrinking home ranges.

Because of the imprecision of available maps, the main difficulty was, first, to locate our positions in the flooded forest and to locate the new islands precisely on the maps. The flooded area was patrolled systematically by two groups of people, one based at the dam and the other at a field camp $44 \mathrm{~km}$ upstream. Capture locations were recorded according to a 0.25-nauticalmile $(463-\mathrm{m})$ grid. Two main capture methods were used: searching in potential refuges (hollow trees, fallen logs, epiphytes and in the canopy) and live-trapping 
(Tomahawk Live Trap Company, snares). The animals were caught either on the ground on isolated islands or in trees above water by climbing or cutting down the shelter tree. The animals were restrained by hand, with a variety of nets and lassos, or by darting. The surface and altitude of each trapped island was estimated and a constant trapping method was used (Fournier-Chambrillon et al., unpublished data).

\section{Collection of data and samples}

The animals were brought to the veterinary facility in individual cages, systematically anesthetized and examined before release. After species identification, a full set of data (capture location, sex, weight, body dimensions and the results of a clinical examination) were recorded, and biological samples (blood, parasites, skin biopsies and venom), were collected for a large majority of the animals. Every animal was tattooed and visually identified with coloured tags before release. Additional animals were captured or collected outside the dam area in order to increase the species diversity of our biological bank and database. They were mainly dead animals, found along the access road to the dam, on the nearby beach (manatee) or killed by hunters.

\section{Post-translocation survey}

The use of two criteria, probability of capture and knowledge of the biology of the species, led to the choice of five species for the post-translocation survey: red howler monkey Alouatta seniculus, white-faced saki Pithecia pithecia, two-toed sloth Choloepus didactylus, three-toed sloth Bradypus tridactylus and grey brocket deer Mazama gouazoubira. Howlers are among the best studied Neotropical mammals and provide a basis for the analysis of individual behaviour following translocation. In contrast, sakis are impossible to study in undisturbed habitats because they are uncommon and shy; as a result they remain poorly known. Although more common, brocket deer also remain poorly known, which is unfortunate because as a game species we were unable to learn enough about them to develop an effective conservation strategy. For these two last species, the rescue provided a capture and study opportunity. Finally, sloths are very common and not too difficult to capture but their biology remains enigmatic and we took advantage of the large sample size to increase our knowledge of these species.

\section{Results and comparison with similar operations}

\section{Captures}

As a result of the unusually low rainfall in 1994, the filling of the reservoir took more than a year. Capture operations were conducted during the flooding, be- tween January 1994 and July 1995 with a maximum at the end of the first rainy season between May and August 1994.

Captures occurred along the Sinnamary River and its tributary streams up to $70 \mathrm{~km}$ from the dam (Fig. 1). In total the captures took place over 1774 boat-days. Onethird of the effort was specifically dedicated to arboreal mammals. Trapping was conducted on 175 islands. A total of 3278 mammals (47 species), 799 snakes (68 species) and 1386 tortoises Geochelone denticulata were captured including 1221 mammals (15 species) and 214 tortoises captured during 25,341 trap-nights (Table 2; Fournier-Chambrillon et al., unpublished data). Seventy-six mammals of 23 species were captured outside the flooded area (Table 2), and 53 per cent of the snakes were captured along the road access to the dam. Fiftytwo animals were radio-collared: 16 red howler monkeys, 5 white-faced sakis, 14 two-toed sloths, 15 three-toed sloths and 2 grey brocket deer. The biological material collected is available for future investigations.

It is difficult to compare our results with other dam rescues because, for most of them, we have no idea of the areas in which the rescues were performed, or how effectively the methodology was applied. The Tucurui operation recorded by far the largest number of rescued mammals and tortoises per sq km 10-20 times more than for the other dams (Table 1). Perhaps this was because the reservoir that formed is one of the largest and deepest, and filled quickly. At Petit Saut, during the course of the operation the number of animals rescued varied greatly with rainfall, and thus with the rapidity of the filling of the reservoir. For example, trapping success reached a maximum of $>10$ per cent at the end of the first rainy season (May; FournierChambrillon et al., unpublished data). Figure 2 compares capture results at various South American reservoirs. Few primates were captured at Petit Saut, which is the smallest and the shallowest of the five dams; the canopy was not flooded and the banks were not too distant, allowing the animals to escape easily; in contrast, more opossums were captured at Petit Saut, probably as a result of more intensive trapping. At Tucuruí there was an attempt to estimate rescue efficiency of primates (Peres \& Jones, 1991-92); the main factor influencing capture frequency was the ability of each species to survive in isolated tree tops. At Petit Saut there were no isolated tree crowns so most monkeys were able to escape and take refuge on the nearest dry land. This was confirmed when an 89-ha area of flooded forest was isolated by clear cutting, thus preventing the escape of arboreal animals: 10 per cent of the monkeys (23 out of 228) were captured in this small area, which amounted to $<0.3$ per cent of the total flooded forest. 
Table 2 List of captured mammals at Petit Saut, French Guiana

\begin{tabular}{|c|c|c|c|}
\hline Orders & Species & Common name & Number \\
\hline & & & 1165 \\
\hline \multirow[t]{16}{*}{ Rodents } & Coendou prehensilis & Brazilian porcupine & 92 \\
\hline & Coendou melanurus* & Hairy dwarf porcupine & 59 \\
\hline & Myoprocta acouchy & Red acouchy & 355 \\
\hline & Agouti paca* & Paca & 30 \\
\hline & Dasyprocta agouti ${ }^{*}$ & Red-rumped agouti & 92 \\
\hline & Hydrochaeris hydrochaerist & Capybara & 1 \\
\hline & Sciureus aestuans & Guianan squirrel & 5 \\
\hline & Sciurillus pusillus & Neotropical pigmy squirrel & 2 \\
\hline & Proechimys sp. & Spiny rat & 463 \\
\hline & Echimys chrysurus & White-faced tree rat & 29 \\
\hline & Makalata didelphoides & Red-nosed tree rat & 25 \\
\hline & Isothrix sinnamariensis & Brush-tailed rat & 2 \\
\hline & Mesomys hispidus & Spiny tree rat & 1 \\
\hline & Oryzomys sp. & Rice rat & 8 \\
\hline & Rhipidomys sp. & Climbing rat & 1 \\
\hline & & & 535 \\
\hline \multirow[t]{7}{*}{ Opossums } & Didelphis marsupialis* & Common opossum & 204 \\
\hline & Didelphis albiventris & White-eared opossum & 41 \\
\hline & Philander opossum* & Gray four-eyed opossum & 177 \\
\hline & Metachirus nudicaudatus & Brown four-eyed opossum & 87 \\
\hline & Caluromys philander & Bare-tailed wooley opossum & 25 \\
\hline & Micoureus demerarae & Wooley mouse opossum & 1 \\
\hline & & & 1276 \\
\hline \multirow[t]{8}{*}{ Xenarthra } & Bradypus tridactylus* & Three-toed sloth & 647 \\
\hline & Choloepus didactylus* & Two-toed sloth & 321 \\
\hline & Tamandua tetradactyla* & Tamandua & 54 \\
\hline & Cyclopes didactylust & Silky anteater & 1 \\
\hline & Dasypus novemcinctus & Nine-banded armadillo & 188 \\
\hline & Dasypus kappleri & Long-nosed armadillo & 63 \\
\hline & Cabassous unicinctust & Naked-tailed armadillo & 2 \\
\hline & & & 229 \\
\hline \multirow{5}{*}{ Primates } & Alouatta seniculus & Red howler monkey & 124 \\
\hline & Saguinus midas* & Golden-handed tamarin & 98 \\
\hline & Pithecia pithecia & White-faced saki & 6 \\
\hline & Ateles paniscus* & Black spider monkey & 1 \\
\hline & & & 49 \\
\hline \multirow[t]{12}{*}{ Carnivores } & Nasua nasua & Coati & 5 \\
\hline & Potos flavus & Kinkajou & 14 \\
\hline & Eira barbara* & Tayra & 8 \\
\hline & Galictis vittatat & Grison & 1 \\
\hline & Leopardus pardalis* & Ocelot & 8 \\
\hline & Leopardus wiedii* & Margay & 2 \\
\hline & Herpailurus yagouaroundi + & Jaguarundi & 1 \\
\hline & Puma concolort & Puma & 2 \\
\hline & Panthera oncat & Jaguar & 4 \\
\hline & Procyon cancrivorust & Crab-eating raccoon & 3 \\
\hline & Speothos venaticust & Bush dog & 1 \\
\hline & & & 23 \\
\hline \multirow[t]{3}{*}{ Artiodactyla } & Mazama gouazoubira & Gray brocket deer & 9 \\
\hline & Mazama americana & Red brocket deer & 4 \\
\hline & Tayassu tajacu & Collared peccary & 10 \\
\hline Manatees & Trichechus manatus* & West Indian manatee & 1 \\
\hline Total & & & 3278 \\
\hline
\end{tabular}

Species names follow Emmons \& Feer (1997), the most recent reference dedicated to neotropical rain forest mammals.

* At least one specimen of this species was collected outside the dam (found dead on roads or beach or killed by hunters).

t Species captured only outside the dam for which partial data or samples were collected. 


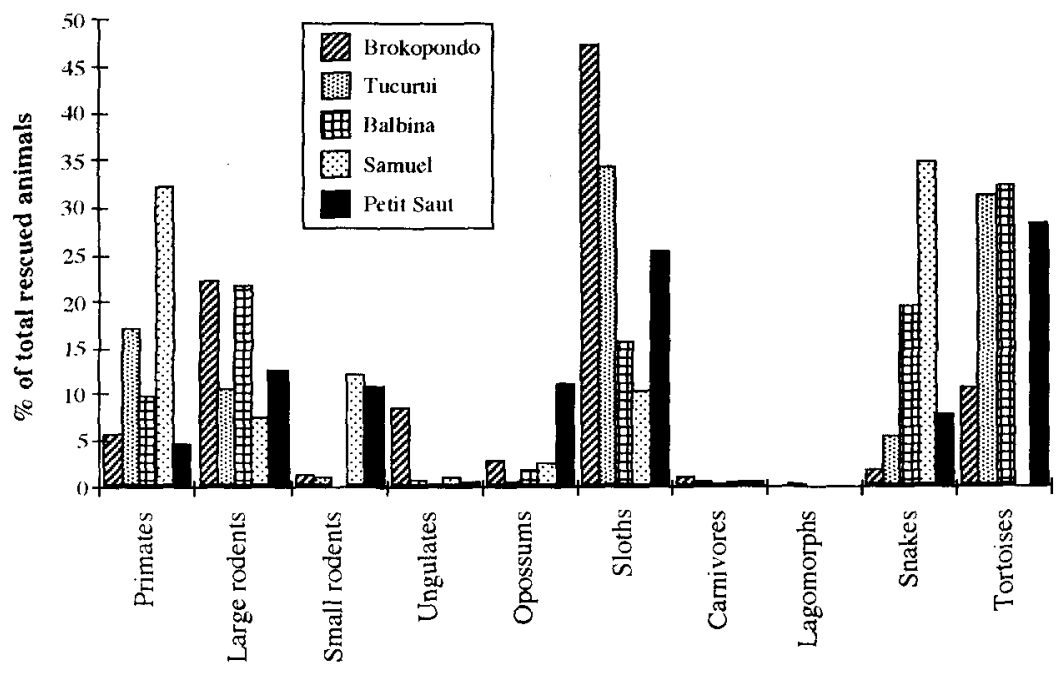

Fig. 2 Percentage of mammal orders, snakes and tortoises rescued at five hydroelectric reservoirs in Neotropical rain forests. Small rodents include Sciuridae, Muridae, Heteromyidae and Echimyidae families. Lagomorphs were present only at Tucuruí.
The rescue success, i.e. the proportion of animals present in the forest before flooding that could be captured and translocated, is impossible to assess. The initial densities of many species and the number of animals that escaped or died in the flooded forest are unknown. The overall observed mortality (animals found dead in the lake, or that died during capture, captivity or after release) was 6 per cent but the true number was probably much greater, especially for smaller species.

At Petit Saut, captures were performed in about $125 \mathrm{sq} \mathrm{km}$, half on land comprising 238 islands (terrestrial animals) and half in flooded areas (arboreal ones). Arboreal mammals were captured in only 1520 per cent of the total flooded forest, other areas being of difficult access, bordered by very tall trees or dedicated to the study of the long-term effects of the dam on wildlife populations as a result of habitat fragmentation (Granjon et al., 1996). Unfortunately, this kind of information is not available for other dams and shows that the retrospective estimates of densities and biomass from rescue results are unreliable, and one should be very cautious in using capture lists (Eisenberg \& Thorington, 1973; Gribel, 1993). In the literature, sloth density estimates vary from $<1$ to 1000 per sq $\mathrm{km}$. Our results show an estimated density of 13.5 per sq $\mathrm{km}$ (Taube et al., in press). Regarding tortoises, our 30 per sq $\mathrm{km}$ estimate is similar to those reported for other Amazonian areas (Richard-Hansen et al., unpublished data). Captures also allowed us to collect biometric measurements on 40 species of Guianan mammals (Richard-Hansen et al., in press).

What was learnt on species diversity and status

Some animals are so poorly known or rare that such rescue operations offer a unique opportunity to discover new species or learn the status of others. In the case of Petit Saut, the discovery of a new rodent species (genus Isothrix: Vié et al., 1996), new records of snake species (Xenopholis scalaris and Drepanoides anomalus) for French Guiana (Vidal et al., in press), and new parasites showed again that Neotropical rain forests still hold secrets in terms of species diversity of higher vertebrates. The hairy dwarf porcupine Coendou melanurus, which was considered to be rare (Emmons \& Feer, 1997), is in fact probably very elusive rather than rare, because 39 per cent of captured porcupines were this species. On the other hand, not one silky anteater Cyclopes didactylus was observed at Petit Saut, whereas 161 had been captured at the nearby Brokopondo dam. Capture location records allowed us to document the sympatry of two sibling opossum species (genus Didelphis: Catzeflis et al., 1997).

In addition, the genetic characterization of each species and the determination of its genetic population structure are important for the development of conservation strategies. The first genetic analyses using material collected at Petit Saut permitted a test of existing taxonomy (Vidal et al., 1997), the characterization of a new mammal species (Vié et al., 1996), the recognition of sibling species (Lavergne et al., 1997) and tests of phylogeographic evolution hypotheses (Vassart et al., 1996; Eizirik et al., 1998). As an example, distinct geographic clusters have been identified for howler monkeys (Vassart et al., 1996) and ocelots (Eizirik et al., 1998) in French Guiana and northern Brazil, and will have to be considered in the management of these species. More genetic studies can now be conducted using frozen cells or DNA of Guianan species without the need for further collecting. 


\section{Diseases}

The first analyses performed by direct examination in our laboratory just after capture showed that $>25$ per cent of captured mammals (and $>90$ per cent of the species) were positive for trypanosomiasis or microfilariasis. More specific studies allowed us to start an inventory of Guianan wildlife parasites: a list of fleas was compiled (Beaucournu et al., 1998), new hemiparasites were identified on snakes (Bothrops atrox, Dipsas indica, Pseustes poecylonatus: J.-C. Michel, pers. comm.), opossums (Didelphis albiventris) and porcupines (Coendou prehensilis; B. de Thoisy, pers. comm.), and a new myiasis species was collected (M. Hall, pers. comm.). Thanks to serological studies, the importance of wild mammals (B. de Thoisy, personal communication) and particularly monkeys (Talarmin et al., 1998) in the sylvatic cycles of several arboviruses could be established.

\section{Translocation methodology and success}

The Petit Saut rescue provided an opportunity to test restrain and anesthetic techniques in field conditions on a large number of wild individuals and species (Fournier-Chambrillon et al., 1997; Fournier et al., 1998; Vié et al., 1998a; Vogel et al., 1998). It was also an opportunity to determine baseline physiological parameters (Vié et al., 1998b), which will be helpful in evaluating future translocation candidates and in captive management.

It was difficult to evaluate survival rates for each species but, based on radio-tagged individuals radiotracked until transmitter exhaustion (up to 18 months), 75 per cent of the animals survived. Six howler monkeys, one saki, four two-toed sloths and two three-toed sloths were found dead. At least three deaths were due indirectly to the collar, which allowed the fatal invasion of the larvae of New World screwworm fly Cochliomya hominivorax.

Three tortoises and two sakis were located more than $10 \mathrm{~km}$ from the release site but the majority settled nearby (Vié et al., 1997). Moreover, social animals such as howler monkeys exhibited undisturbed behavioural patterns and were integrated into resident groups (Vié \& Richard-Hansen, 1997). The post-release survey afforded unique opportunities to study other species; for example, thanks to radio-tracking, it was possible to habituate saki monkeys to human presence and we found that the home range of this species was 20 times larger than previously thought, reaching over 200 ha (Vié \& Richard-Hansen, 1997). It was also interesting to observe that for this species roads are impassable obstacles.

\section{Costs}

Financial aspects of wildlife rescues are rarely de- scribed. At Brokopondo the first estimation of the cost was $\$ U S 80,000-\$ U S 100,000$ per year (in 1964) for around 10,000 rescued animals (Walsh \& Gannon, 1967). The overall cost of the Exxon Valdez oil spill rescue has been estimated at \$US45 million and around 2000 animals were rescued (Monahan \& Maki, 1991). The difference is extreme but is explicable: 25 years separate the two events; concern about conservation of nature has greatly increased; legislation has been improved; and public and media pressure have become stronger. In addition, in the case of the Exxon Valdez, the damage was reversible and so it may have merited higher efforts. The estimated cost of the Tucuruí dam rescue was \$5-10 million (Eletronorte, pers. comm.). The cost of the Petit Saut rescue was FF20 million francs (\$US3.3 million). A full comparison requires taking into account not just the number of animals captured but the overall research programme and the cost of employing 35 French professionals.

Comparison of recent rescues/translocations of two endangered mammal species illustrates the funding differences regarded as acceptable under different circumstances: \$US14,700 for 84 orang-utans (\$US175/animal) in Malaysia (Andau et al., 1994) and \$US18.3 million for 357 sea otters (\$US71,206/animal) during the Exxon Valdez oil spill in Alaska, USA (Estes, 1991). Costs of translocations conducted in the USA in 1985 ranged from a few dollars per small mammal (squirrels or hares) to $\$ U S 4000$ for elk (Boyer \& Brown, 1988). Even in developed countries such as the USA, cost is the most frequently reported reason given by state agencies for not conducting more translocations (Boyer $\&$ Brown, 1988). The same applies in developing countries; in India for example, \$US32 spent on each translocated commensal rhesus monkey in 1990 is prohibitive, considering the number of candidates for translocation (Malik \& Johnson, 1994). However, the cost of not translocating individuals could be higher when one takes into account potential monkey to human transmission of disease and crop depredations. Field studies conducted to monitor the effects of translocation considerably raise the total cost and might be prohibitive in countries with limited financial resources. For example the cost of translocating a baboon troop in Kenya was estimated at around \$US500 per animal (Strum \& Southwick, 1986), three times more than for the endangered orang-utan (Andau et al., 1994) and almost the same amount that we spent in French Guiana 10 years later (\$US650/animal).

On the other hand, there is an urgent need to inventory biological resources and their status for sustainable use (Scheuer, 1993). The provisional budget of the 'all taxa biodiversity inventory' in the 110,000-ha Guanacaste conservation area in Costa Rica has been estim- 
ated as \$US120 million (Brooks, 1996). Given the opportunity of captures and access to the canopy at Petit Saut we regret that a similar project involving the whole scientific community was not initiated there. As an example, almost no study was undertaken of species in the canopy (e.g. plants, micromammals, amphibians and invertebrates).

\section{Conclusion}

Beyond the successful translocation of thousands of animals, the rescue allowed the collection of biological material and data that otherwise would have disappeared. However, habitat destruction is a major threat to wildlife and prevention must mobilize the maximum of efforts (Estes, 1991). The rescue was an emergency operation, which does not compensate for the loss of such a large area of intact natural habitat. However, the symbolic aspect of translocation or reintroduction operations should not be neglected because they are an excellent way to focus public attention on conservation problems.

The creation of reserves is a classic compensatory measure when hydroelectric dams are built (McNeely, 1987). In the present case, it was necessary to wait for the building of a large dam to establish the first large protected area in the country. However, Petit Saut's protected status is low (it is protected locally by a decree issued by the Préfet, the highest French representative in French Guiana). While the rescue operation was taking place it was well patrolled by scientists, archaeologists and guards, and the main entrance was controlled. However, its future is not guaranteed. Patrols have now been greatly reduced and there has been no progress to improve its legal status. The Petit Saut area is one of the best known areas in French Guiana as far as archeological, hydrobiological and wildlife studies are concerned, and it is of great importance to take this area into account in the elaboration of conservation strategies.

In 1994 the French Minister of the Environment said that the Petit Saut dam was a trigger for conservation. Before Petit Saut there was only one natural reserve with national status: a small offshore island with a colony of seabirds, which was established in 1992. Soon after the filling of the dam and the completion of the rescue, the first natural forest reserves were created: Les Nourages, 100,000 ha of rain forest in 1995; La Trinité, 76,000 ha of rain forest in 1996; Kaw-Roura, 94,700 ha of forest, swamp and mangrove in 1998; and L'Amana, 14,800 ha of seashore and mangrove in 1998. A new conservation dynamic has appeared in the political arena. Those who had reservations about the usefulness of the Petit Saut wildlife and other environmental studies may, in retrospect, change their opinions.

\section{Acknowledgements}

First I would like to thank all the persons who participated actively in the operation under difficult field conditions: C. Genty, P. Fournier, C. Richard-Hansen, C. Fournier-Chambrillon, N. Vidal, J. Kéravec, E. Taube, B. de Thoisy, T. Groueix, F. Madelénat, I. Vogel, P. Chabaud, E. Pinault, I. Lemercier, J.-J. Meynard, N. Bello, N. Perrin, J. M. Denis, X. Barbe, S. Yarde, C. Bracq, E. Mérigeon, C. Meynier, F. Vilain, L. Achille, G. D. and A. Amoida, L. Beni, P. Bruno, P. Caberia, P. Chambon-Perrier, P. Cosset, S. Cyrille, V. Joigny, A. Kanape, B. Madeleine, L. Mather, A. Mendes and A. Oscar. Thanks to F. Macé, J.-M. Rodriguez, E. Hansen and J.-M. Angibault for their assistance. I am grateful to C. Richard-Hansen, F. Moutou, F. Catzeflis, J.-F. Cosson, J.-M. Pons, O. Poncy and C. Sissakian for their constructive comments on the manuscript and to $R$. Sinha for the revision of the language. I am also grateful to all the people who helped me to obtain all the unpublished documents on previous rescues and especially Drs J. Eisenberg and G. Child for the precious information on Guri and Kariba dams. This work was part of environmental studies funded by Electricité de France/Centre National d'Equipement Hydraulique. I am grateful to D. Pélissier, C. Sissakian, B. Deschard, J.-F. Astolfi, M. Robino, G. Authier and A. Demo for help and support. Association Kwata also provided great support for the publication of this manuscript.

\section{References}

Andau, P.M., Hiong, L.K. \& Sale, J.B. (1994) Translocation of pocketed orang-utans in Sabah. Oryx, 28, 263-268.

Beaucournu, J.-C., Reynes, J.-M. \& Vié, J.-C. (1998) Contribution towards a catalogue of fleas from French Guiana (Insecta: Siphonaptera). Journal of Medical Entomology, 35, 3-10.

Berducou, C. (1990) Chamois et isard: bilan des translocations réalisées en France (1956-1988). Revue dEcologie (Terre et Vie), 5(Suppl.), 121-130.

Boyer, D.A. \& Brown, R.D. (1988) A survey of translocations of mammals in the United States 1985. In Translocation of Wild Animals (eds L. Nielsen and R. D. Brown), pp. 1-11. The Wisconsin Humane Society Inc. \& The Caesar Kleberg Wildlife Research Institute, Milwaukee, WI, USA.

Brooks, D.R. (1996) The all taxa biodiversity inventory in the Guanacaste conservation area, Guanacaste province, Costa Rica. In Proceedings of the Annual Conference of the American Association of Zoo Veterinarians, pp. 343-349. Puerto Vallarta, Mexico.

Caldecott, J. \& Kavanagh, M. (1988) Strategic guidelines for nonhuman primate translocation. In Translocation of Wild Animals (eds L. Nielsen and R. D. Brown), pp. 64-75. The Wisconsin Humane Society Inc. \& The Caesar Kleberg Wildlife Research Institute, Milwaukee, WI, USA. Catzeflis, F.M. (1991) Animal tissue collections for molecular 
genetics and systematics. Trends in Ecology and Evolution, 6, 168.

Catzeflis, F.M., Richard-Hansen, C., Fournier-Chambrillon, C., Lavergne, A. \& Vié, J.-C. (1997) Nouvelles données sur la présence sympatrique en Guyane de Didelphis marsupialis et D. albiventris (Didelphidae: Marsupiala). Mammalia, 61, 231-243.

Charity, S., Buschinelli, M.C., Gasparini, R.L., Tomas, W., Nunes, A., Oliveira, P., Santiago, M.E. \& Cury, M. (1991) Translocation of a total marsh deer (Blastocerus dichotomus) population at Tiete river, São Paulo State, Brazil. In Abstracts of the XXIV World Veterinary Congress, p. 194. Rio de Janeiro, Brazil.

Child, G. (1968) Behaviour of Large Mammals during the Formation of Lake Kariba. Rhodesia Kariba Studies, Mardon Printers, National Museums of Rhodesia, Salisbury and Bulawayo.

Cunningham, A.A. (1996) Disease risks of wildlife translocations. Conservation Biology, 10, 349-353.

Dessauer, H.C. \& Hafner, M.S. (1984) Collections of frozen tissues: value, management, field and laboratory procedures, and directory of existing collections. Association of Systematics Collections, University of Kansas, Lawrence, KS, USA.

Dietz, J.M., Dietz, L.A. \& Nagagata, E.Y. (1994) The effective use of flagship species for conservation of biodiversity: the example of lion tamarinds in Brazil. In Creative Conservation: Interactive Management of Wild and Captive Animals (eds P. J. S Olney, G. M. Mace and A. T. C. Feistner), pp. 32-49. Chapman \& Hall, London.

Dorrestein, G.M., Peeters, H. \& Binsbergen, A. (1994) The organization of rescue and rehabilitation of oil-polluted birds in the Netherlands. In Wildlife and Oil Spills: Response, Research, and Contingency Planning (ed. L. Frink), pp. 145-150. Tri-state Bird Rescue \& Research Inc, Newark, DE, USA.

Ehrlich, P.R. \& Wilson, E.O. (1991) Biodiversity studies: science and policy. Science, 253, 758-762.

Eisenberg, J.F. \& Thorington Jr., R.W. (1973) A preliminary analysis of a neotropical mammal fauna. Biotropica, 5 , 150-161.

Eizirik, E., Bonatto, S.L., Johnson, W.E. et al. (1998) Phylogeographic patterns and evolution of the mitochondrial DNA control region sequences in two neotropical cats (Mammalia, Felidae). Journal of Molecular Evolution, 47, 613-624.

Eletronorte (1985) Usina hidrelétrica de Tucuruí. Fauna: relatório final. Analise da operação Curupira. Internal Report, Brasília, Brazil.

Eletronorte (1988) Atividades desenvolvidas pelo IBDF no acompanhamento do resgate de fauna na usina hidrelétrica Balbina. Relatório final. Internal Report, Brasília, Brazil.

Eletronorte (1989) Usina hidrelétrica Samuel. Relatório da operaçāo Jamari. Internal Report, Brasília, Brazil.

Emmons, L.H. \& Feer, F. (1997) Neotropical Rainforest Mammalsa Field Guide, 2nd edn. The University of Chicago Press, Chicago, USA.

Erwin, T.L. (1991) An evolutionary basis for conservation strategies. Science, 253, 750-752.

Estes, J.A. (1991) Catastrophes and conservation: lessons from sea otters and the Exxon Valdez. Science, 254, 1596.

Fournier, P., Fournier-Chambrillon, C. \& Vié, J.-C. (1998) Immobilization of wild kinkajous (Potos flavus) with a medetomidine-ketamine combination and reversal with atipamezole. Journal of Zoo and Wildlife Medicine, 29, 190-194.

Fournier-Chambrillon, C., Fournier, P. \& Vié, J.-C. (1997)
Immobilization of wild collared anteaters (Tamandua tetradactyla) with ketamine- and xylazine-hydrochloride combinations. Journal of Wildlife Diseases, 33, 795-800.

Ghilardi, R., Jr. \& Juras, I.A.G.M. (1991) Rescue of fauna from 'Samuel' reservoir, State of Rondônia, Brazil. In Abstracts of the XXIV World Veterinary Congress, p. 321. Rio de Janeiro, Brazil.

Granjon, L., Cosson, J.-F., Judas, J. \& Ringuet, S. (1996) Influence of tropical rainforest fragmentation on mammal communities in French Guiana: early trends. Acta Oecologica, 17, 673-684.

Gribel, R. (1993) Os mamíferos silvestres e as grandes barragens na Amazônia. In Bases cientificas para estratégias de preservação e desenvolvimento da Amazônia, vol. 21 (eds E. J. G. Ferreira, G. M. Santos, E. L. M. Leão and L. A. Oliveira), pp. 125-133. Instituto Nacional de Pesquisas da Amazônia, Manaus, Brazil.

Griffith, B., Scott, J.M., Carpenter, J.W. \& Reed, C. (1989) Translocation as a species conservation tool: status and strategy. Science, 245, 477-480.

Harthoorn, A.M. (1962) Translocation as a means of preserving wild animals. Oryx, 6, 215-227.

Hodder, K.H. \& Bullock, J.M. (1997) Translocations of native species in the UK: implications for biodiversity. Journal of Applied Ecology, 34, 547-565.

Holcomb, J. (1991) Overview of bird search and rescue, and response efforts during the Exxon Valdez oil spill. In Proceedings of the 1991 Oil Spill Conference, pp. 225-228. American Petroleum Institute, Washington, DC, USA.

Horwich, R.H., Koontz, F., Saqui, E., Saqui, H. \& Glander, K. (1993) A reintroduction program for the conservation of the black howler monkey in Belize. Endangered Species Update, 10, $1-6$.

IUCN (1995) Draft Guidelines for Re-introductions. Species Survival Commission/Re-introduction Specialist Group, IUCN-The World Conservation Union, Gland, Switzerland.

IUCN (1998) Guidelines for Re-introductions. Species Survival Commission/Re-introduction Specialist Group, IUCN-The World Conservation Union, Gland, Switzerland.

Karesh, W.B. \& Cook, R.A. (1995) Applications of veterinary medicine to in situ conservation efforts. Oryx, 29, 244-252.

Kinzey, W.G., Norconk, M.A. \& Alvarez-Cordero, E. (1988) Primate survey of Eastern Bolívar, Venezuela. Primate Conservation, 9, 66-70.

Kleiman, D.G., Stanley-Price, M.R. \& Beck, B.B. (1994) Criteria for reintroductions. In Creative Conservation: Interactive Management of Wild and Captive Animals (eds P. J. S. Olney, G. M. Mace and A. T. C. Feistner), pp. 287-303. Chapman \& Hall, London.

Konstant, W.R. \& Mittermeier, R.A. (1982) Introduction, reintroduction and translocation of Neotropical primates: past experiences and future possibilities. International Zoo Yearbook, 22, 69-77.

Lavergne, A., Verneau, O., Patton, J.L. \& Catzeflis, F.M. (1997) Molecular discrimination of two sympatric, sibling species of opossum (genus Didelphis: Didelphidae) in French Guiana. Molecular Ecology, 6, 889-891.

Loughlin, T.R. (1994) Marine Mammals and the Exxon Valdez. Academic Press, San Diego, USA.

Malik, I. \& Johnson, R.L. (1994) Commensal rhesus in India: the need and cost of translocation. Revue d'Ecologie (Terre et Vie), 49, 233-243.

Mascarenhas, B.M. \& Puorto, G. (1988) Nonvolant mammals rescued at the Tucuruí dam in the Brazilian Amazon. Primate Conservation, 9, 91-93. 
McNeely, J.A. (1987) How dams and wildlife can coexist: natural habitats, agriculture, and major water resource development projects in tropical Asia. Conservation Biology, 1, 228-238.

Monahan, T.P. \& Maki, A.W. (1991) The Exxon Valdez 1989 wildlife rescue and rehabilitation program. In Proceedings of the 1991 Oil Spill Conference, pp. 131-136. American Petroleum Institute, Washington, DC, USA.

Monnat, J.-Y. \& Guermeur, Y. (1979) L'Amoco-Cadiz et les oiseaux. Société Nationale de Protection de la Nature, Brest, France.

Morowitz, H.J. (1991) Balancing species preservation and economic considerations. Science, 253, 752-754.

Nakhasathien, S. (1989) Chiew Larn dam wildlife rescue operation. Oryx, 23, 146-154

Nielsen, L. (1988) Definitions, considerations, and guidelines for translocation of wild animals. In Translocation of Wild Animals (eds L. Nielsen and R. D. Brown), pp. 12-49. The Wisconsin Humane Society Inc. \& The Caesar Kleberg Wildlife Research Institute, Milwaukee, WI, USA

Orr, D.W. (1992) For the love of life. Conservation Biology, 6, 486-487.

Peres, C.A. \& Jones, A.D. (1991-92) Patterns of primate mortality in a drowning forest: lessons from the Tucuruí dam, Brazilian Amazonia. Primate Conservation, 12-13, 7-10.

Richard-Hansen, C., Vié, J.-C., Vidal, N. \& Kéravec, J. (in press) Biometrical data on 40 species of mammals from French Guiana. Journal of Zoology.

Rodríguez-Luna, E., García-Orduña, F. \& Canales-Espinosa, D. (1993) Translocación del mono aullador Alouatta palliata: una alternativa conservacionista. In Estudios primatológicos en México, vol. 1 (eds A. Estrada, E. Rodríguez-Luna, R. López-Wilchis and R. Coates-Estrada), pp. 129-177. Universidad Veracruzana, Xalapa, Veracruz, Mexico.

Sarrazin, F. \& Barbault, R. (1996) Reintroduction: challenges and lessons for basic ecology. Trends in Ecology and Evolution, 11, $474-478$.

Scheuer, J.H. (1993) Biodiversity: beyond Noah's ark. Conservation Biology, 7, 206-207.

da Silva, M.N. \& Patton, J.L. (1993) Amazonian phylogeography: mtDNA sequence variation in arboreal echimyid rodents (Caviomorpha). Molecular Phylogeny and Evolution, 2, 243-255.

Sioli, H. (1986) Sensitive habitats: threats and managementtropical continental aquatic habitats. In Conservation Biology: the Science of Scarcity and Diversity (ed. M. E. Soulé), pp. 383-393. Sinauer, Sunderland, MS, USA.

Sissakian, C. \& Vié, J.-C. (1997) Wildlife conservation and monitoring at Petit Saut. Hydropower and Dams, 4, 25-30.

Smithers, R.H.N. (1959) The Kariba lake. Oryx, 5, 21-24.

Soulé, M.E. (1986) Conservation Biology: the Science of Scarcity and Diversity. Sinauer, Sunderland, MA, USA.

Soulé, M.E. (1991) Conservation: tactics for a constant crisis. Science, 253, 744-750.

Strum, S.C. \& Southwick, C.H. (1986) Translocation of primates. In Primates, the Road to Self-sustaining Populations (ed. K. Benirschke), pp. 949-958. Springer-Verlag, New York, USA.

Talarmin, A., Chandler, L.J., Kazanji, M. et al. (1998) Mayaro virus fever in French Guiana: isolation, identification and seroprevalence. American Journal of Tropical Medicine and Hygiene, 59, 452-456.

Taube, E., Vié, J.-C., Fournier, P., Genty, C. \& Duplantier, J.-M (in press) Distribution of two sympatirc species of sloths
(Choloepus didactylus and Bradypus tridactylus) along the Sinnamary River, French Guiana. Biotropica.

de Thoisy, B. \& Vié, J.-C. (in press) Faune Sauvage et activités humaines: exploitation forestière et chasse en Guyane Française. Journal d'Agriculture Traditionnelle et Botanique Appliquée.

Vassart, M., Guédant, A., Vié, J.-C., Kéravec, J., Séguéla, A. \& Volobouev, V.T. (1996) Chromosomes of Alotatta seniculus (Platyrrhini, Primates) from French Guiana. The Journal of Heredity, 87, 331-334.

Vidal, N., Lecointre, G., Vié, J.-C. \& Gasc, I.-P. (1997) Molecular systematics of pitvipers: paraphyly of the Bothrops complex. Compte rendus de l'Académie des Sciences (Série 3), 320, 95-101.

Vidal, N., de Massary, J.C. \& Marty, C. (in press) Quatre nouvelles espèces de serpents pour la Guyane Française. Revue Française d'Aquariologie.

Vié, J.-C. \& Richard-Hansen, C. (1997) Primate translocation in French Guiana-a preliminary report. Neotropical Primates, 5, $1-3$

Vié, I.-C., Richard-Hansen, C. \& Taube, E. (1997) Wildlife translocation in French Guiana-a preliminary report. Re-introduction News, 13, 7-9.

Vié, J.-C., de Thoisy, B., Fournier, P., Fournier-Chambrillon, C., Genty, C. \& Kéravec, J. (1998a) Anesthesia of wild red howler monkeys (Alouatta seniculus) with medetomidine-ketamine and reversal by atipamezole. American Journal of Primatology, 45, 399-410

Vié, J.-C., Moreau, B., de Thoisy, B., Fournier, P. \& Genty, C. (1998b) Hematology and serum biochemistry values in wild red howler monkeys (Alouatta seniculus). Journal of Zoo and Wildiffe Medicine, 29, 142-149.

Vié, J.-C., Volobouev, V., Patton, J.L. \& Granjon, L. (1996) A new species of Isothrix (Rodentia: Echimyidae) from French Guiana. Mammalia, 60, 393-406.

Vogel, I., de Thoisy, B. \& Vié, J.-C. (1998) A comparison of injectable anesthetic combinations in wild two-toed sloths (Choloepus didactylus). Joumal of Wildlife Diseases, 34, 555-566.

Walsh, J. \& Gannon, R. (1967) Time is Short and the Water Rises. E. P. Dutton \& Co., Inc, New York, USA.

Woodford, M.H. \& Rossiter, P.B. (1993) Disease risks associated with wildlife translocation projects. Revue Scientifique et Technique de l'Office International des Epizooties, 12, 115-135.

\section{Biosketch}

Jean-Christophe Vié is a Doctor in Veterinary Medicine and has recently completed a $\mathrm{PhD}$ thesis on population biology and ecology (University of Montpellier II, France). His main research interests are wildlife studies, health, ecology and conservation, with special interests in non-human primates and Neotropical wildlife. Since 1986 he has worked in Gabon, French Guiana, Saudi Arabia and the USA. He started planning and directing the Petit Saut rescue in 1993 and now directs a non-governmental organization, Kwata (kwata is the local name for the spider monkey) whose aim is the study and conservation of Guianan wildlife. 